\title{
HUBUNGAN EMPATI DENGAN PERILAKU ALTRUISTIK
}

\author{
Roudlotun Ni'mah \\ IAI Sunan Giri Bojonegoro \\ Email: nikmah.syauqi@yahoo.com
}

\begin{abstract}
This study aims to determine the relathionship between empathy with altruistic behavior. Subjects were students in Al-asy'ari boarding school totaling 90 student for male sex between the age of 12 to 25 years. Meansuring intruments used are altruistic behavior scale and empathy scale. The data capture techniques using proportionate stratified random sampling. Methods of data analysis using regression analisysis with SPSS16.0 program. The resulst showed positive significant relationship between empathy and altruistic behavior. Effective contribution of empathy to altruistic behavior for students in Al-asy'ari boarding school is $44 \%$ indicated by the coefficient of determinant (R2) 44,0. This means there is 66,4\% of other variables that affect students' altruistic behavior."
\end{abstract}

Keywords: Empathy, altruistic behavior

\section{PENDAHULUAN}

Kemajuan zaman semula dipandang akan memudahkan pekerjaan manusia, kenyataannya menimbulkan keresahan dan ketakutan, kesepian dan keterasingan baru, yang ditandai dengan lunturnya solidaritas, kebersamaan, silaturahim dan krisis moral juga menjadi bagian yang menambah dert persoalan yang dihadapi bangsa ini, seperti: kasus tawuran antar pelajar, penyiksaan terhadap guru dan adanya tragedy contek massal yang pernah mencoreng moment ujian nasional di negara kita.

Menurut Azra(2002, dalam Afiatin, 2012) pendidikan nasional telah gagal dalam membentuk peserta didik yang memiliki akhlaq, moral dan budi pekerti. Beberapa diduga ikut menjadi akar krisis mentalitas dan moral, lembaga pendidikan kurang mmenfasilitasi peserta 
didik dalam melatih diri untuk berbuat sesuatu berdasarkan nilai - nilai agama, proses pendewasaan diri tidak berlangsung baik, proses pendidikan sangat mmembelenggu peserta didik, guru/dosen begitu juga beban kurikulum terlalu berat dan hamper sepenuhnya diorientasikan pada pengembangan ranah kognitif belaka.

Salah satu lembaga pendidikan yang menfasilitasi peserta didik dalam melatih diri adalah pondok pesantren. Pondok pesantren merupakan salah satu lembaga pendidikan islam yang bersistem asrama, kyai sebagai figur sentralnya dan masjid sebagai pusat yang menjiwainya. Pesantren menjadi pusat pencerdasan karakter santri, baik spiritual, intelektual dan sosial emosional (Kurniawan, 2012). Lingkungan pesantren secara keseluruhan adalah lingkungan yang dirancang untuk kepantingan pendidikan, sehingga segala yang didengar, dilihat, dirasakan, dikerjakan dan dialami para santri dan seluruh penghuni penghuni pesantren terkondisikan untuk kepentingan pencapean tujuan pendidikan. Demikian pula yang terjadi di pondok pesantren AlAsy’ari Ceweng Dander Bojonegoro.

Berdasarkan observasi peneliti dengan melakukan wawancara beberapa santri dan penyebaran angket, maka peneliti menemukan beberapa permasalahan: 1) sebagian santri kurang peduli terhadap keadaan teman yang kurang dekat/ tidak dikenalnya, 2) sebagian santri akan memberikan memberikan pertolongan apabila ada syarat tertentu, 3) sebagian santri sering melakukan perbuatan yang merugikan orang lain, seperti : mencuri, mengambil tanpa izin (menghosob), 4) sebagian santri kurang peduli dengan lingkungan sekitar misalnya : tidak memungut sampah yang berserakan, tidak merapikan kabar kecuali apabila piket dan lain - lain. Problem - problem tersebut sangat bersebrangan dengan karakteristik pesantren yang mengedepankan solidaritas, kegotong royongan, kebersamaan dan saling tolong menolong secara ikhlas atau dikenal dengan perilaku altruistik.

\section{Perilaku Altruistik}

Istilah "altruisme" (perilaku altruistik) diciptaan sosiolog Perancis, August Comte, berasal dari bahasa Perancis 'le bien d'altru' (kebaikan orang lain). Altruisme aslinya 'Lainisme': usaha atau kemampun yang sebenarnya untuk bertindak demi kepentingan orang lain. Comte menganggap dalam diri individu ada dua motif yang berbeda yaitu egois dan altruistk. Motif mementingkan diri sendiri dalam membantu orang alin, dan mencari manfaat diri sendiri 
diisebut egoism. Sedangkan perilaku sosial yang berkeinginan untuk membantu orang lain, tanpa mengharap imbalan apapun disebut 'altruisme' atau perilu altruistic (Habito \& Inaba, 2006).

Perilaku altruistik didefinisikan sebagai suatu tindakan yang memiliki konsekuensi memberikan beberapa keuntungan atau meningkatkan kesejahteraan orang lain (Dovido dkk, 2006). Menurut Myers (2012) altruisme adalah sebagai hasratuntuk menolong orang lain tanpa memikirkan kepentingan sendiri. Menurut Batson (2008) perilaku altruistik yaitu perilaku yang dimotivasi untuk meningkatkan kesejahteraan orang lain yang tidak mementingkan diri sendiri (selfless) dan bukan hanya mementingkan diri sendiri (selfish). Seorang altruistic hanya mengharapkan ganjaran setelah mereka meninggal (Baron Byrne, 2003). Altruisme didefinisikan sebagai keadaan motivasi dengan tujuan utama untuk meningkatkan kesejahteraan orang lain (Shah Ali, 2012).

Perilaku altruistik merupakan kebalikan dari perilaku egoistik, yaitu perilaku membantu orang lain tanpa mengharap keuntungan yang ditawarkan atau tidak adanya harapan yang akan didapatkan kembali (Myears, 2012). Menurut Laventhal (2009), mendefinisikan perilaku altruistic merupakan perilaku yang dimotivasi untuk meningkatkan kesejahteraaan orang lain.

Mc.Guire dan Neisz (Leontopoulou, 2010), menyebutkan karakteristik perilaku altruistic antara lain: seseorang lebih suka memberi pertolongan, lebih murah hati, mudah bersosialisasi, mampu berinteraksi dengan berbagai karakter orang, lebih popular dengan teman - temannya dan menyadari untuk saling membutuhkan. Altruisme dapat membangun hubungan antara sesama, mengurangi strees dan membawa manfaat dalam kehidupan, antara lain : dapat membangun emosi kesejahteraan terukur dengan meningkatkan ketenangan pikiran. Melalui perilaku altruistik ini juga dapat meningkatkan dukungan sosial dalam masyarakat, menambah rasa syukur (mendapatkan prespektif yang positif), dengan altruisme juga dapat membangun masyarakat yang lebih baik (Elizabeth, 2011).

Myears (2012_ menyatakan bahwa seseorang dapat memiliki kecenderungan altruisme bila di dalam dirinya terkandung komponen - komponen sebagai berikut:

a. Memberi pertoongan kepada orang lain dengan dimotivasi rasa empati 
b. Sukarela, yaitu tidak ada keinginan untuk mendapatkan imbalan. Tindakan ini sematamata dilakukan untuk kepentingan orang lain, bahkan rela mengorbankan nilai - nilai kejujuran dan keadilan yang ada pada dirinya.

c. Keinginan untuk memberi bantuan orang lain yang membutuhkan meskipun tidak ada yang mengetahui bantuan yang telah diberikannya, baik berupa materi maupun waktu.

Menurut Einserberg dan Mussen (Dayakisni \& Hudaniah, 2003) Komponen- komponen perilaku altruistic antara lain:

a. Sharing (memberi), individu yang sering berperilaku altruis biasanya sering memberikn sesuatu bantuan kepada orang lain, yang lebih membutuhkan daripada dirinya.

b. Cooperative (kerjasama), individu yang memiliki sifat altruis lebih senang melakukan pekerjaan secara bersama - sama, karena mereka berfikir dengan bekarja sama mereka dapat bersosialisasi denga sesame.

c. Donating (menyumbang), perilaku altruistik yang dimiliki seseorang, menjadikan individu senang memberikan bantuan tanpa mengharap imbalan apapun.

d. Helping (menolong), orang yang berperilaku altruistic lebih suka memberikan pertolongan, walaupun harus merelakan kepentingan sendiri.

e. Honesty (jujur), seseorang ini lebih memiliki sikap lurus hati, tidak curang dan mengutamakan nilai kejujuran pada dirinya.

f. Generosity (Kedermawanan), individu yang bersifat altruis, lebih suka berderma, memiliki sifat yang murah hati terutama dalam memberikan pertolongan dan bantuan.

Adapun faktor - faktor yang mempengaruhi altruistik menurut Myers (2012) adalah (1) faktor yang mempertimbangkan pengaruh - pengaruh internal terhadap keputusan untuk menolong, hal ini juga termasuk menggambarkan situasi suasana hati, pencapena reward, empati, mood seseorang. (2) faktor eksternal seperti jenis kelamin, kesamaan karakteristik, kedekatan hubungan, tarik antar penolong dan yang ditolong, jumlah pengamatan lain, tekanan waktu, kondisi lingkungan dan antibusi. (3) faktor personal yaitu mempertimbangkan sifat dari penolong, hal ini mencakup sifat - sifat kepribadian, gender dan religiusitas subyek (kepercayaan religius). 
Menurut Sarwono \& Mernarno (2011), perilaku menolong dipicu oleh faktor - faktor luar dan dalam dalam diri individu, yaitu:

a. Faktor eksternal/pengaruh situasi

1) By stander (adanya orang yang bersama kita di tempat kejadian). Semakin banyak orang lain maka semakin kecil kecenderungan untuk memberi pertolongan.

2) Menolong jika orang lain juga menolong, dengan adanya orang lain menolong maka motivasi menolong lebih besar.

3) Desakan waktu. Seseorang yang memiliki kesibukan/ tergesah - gesah biasanya kecenderungan untuk menolong sangat kecil, berbeda dengan orang yang santai.

4) Kemampuan yang dimiliki. Seseorang yang memiliki kemampuan, akan memiliki ras menolong lebih besar, misalnya menyelamatkan orang yang tenggelam.

b. Faktor Internal/ pengaruh dalam diri

1) Perasaan. Perasaan negatif pada anak akan menghambat mereka untuk memberikan pertolongan, akan tetapi bagi orang dewasa kecenderungan menolong lebih besar, karena dengan memberikan pertoongan perasaan negative akan terkurangi.

2) Faktor sifat. Bagi seseorang yang lebih menyukai untuk menolong dikarenakan sifat menolong sudah tertanam dalam jiw mereka.

3) Agama. Kenyakinan agama menjadikan untuk memberikan pertolongan.

\section{Empati}

Kata "empati" diciptakan oleh Ticner berasal dari terjemahan bahasa Jerman yaitu : “einfulung” yang berarti memproyeksikan diri dari dalam apa yang kita amati (Besel \& Yuille). Menurut Allpot (Taufik, 2012), Empati adalah suatu perubahan imajinasi seseorang ke dalam pikiran, perasaan orang lain. Menurut Rongers (Taufik, 2012), empati merupakan kerangka berfikir internal orang lain secara akurat,atau memahami orang lainseolah - olah dirinya masuk pada kehidupan orang tersebut, sehingga merasakan dan mengalami sebagaimana orang lain alami.

Menurut Lerner (Finn, 2008) empati adalah "Jantung" dari pendekatan Psikologis penilaian. Terdapat tiga makna yaitu: (a) sebagai alat pengumpulan informasi, (b) sebagai proses Interpersonal, dan (c) sebagai penyembuhan elemen diri seseorang dalam interaksi manusia. 
Adapun menurut Davis, empati adalah keterampilan sosial mendasar yang memungkinkan individu untuk mengantisipasi, memahami melalui pengalaman yang dimiliki. Menurut Fresbach, empati merupakan penentu penting dalam transaksi sosial. Sedangkan menurut Staub, empati adalah perilaku yang memainkan peran kunci dalam pengembangan pemahaman sosial dan perilaku sosial yang positif (Barr \& Higgin’s, 2007).

Menurut Eklund (2006), mendefinisikan empati sebagai "respon afektif" dengan menempatkan posisi diri sendiriterhadap orang lain, yang berasal penangkapan atau pemahaman orang lain dengan melibatkan kondisi emosionalnya sehingga mampu merasakan yang orang rasakan dan apa yang diharapkan orang lain, orientasinya untuk merespon orang lain dengan melibatkan emosional dirinya. empati juga dapat diartikan sebagai suatu tindakan mencoba untuk merasakan, berbagi dan bagaimana seseorang mengkonsep apa yang orang lain rasakan.

Berdasarkan faktor internal, perilaku altruistik seseorang dapat dipengaruhi oleh empati. Menurut Batson (2008), adanya hubungan empati dengan tingkah laku menolong, empati merupakan sumber dari motivasi altruistik. Empati adalah kemampuan seseorang untuk menempatkan diri dalam perasaan ataupun pikiran orang lain tanpa harus secara nyata terlibat dalam perasaan atau tanggapan orang tersebut (Koetsner dan Franz dalam Taufik, 2012). Menurut Baron bahwa empati adalah kemampuan seseorang untuk bereaksi terhadap emosi negatif atau positif orang lain seolah - olah dialami sendiri (Taufik, 2012).

Adapun aspek -aspek empati, menurut Ambrosio (2009) terdapat empat aspek yaitu:

a. Prespectif Taking, adalah kecenderungan seseorang untuk menilai sudut pandang orang lain secara spontan.

b. Empatic Concent, adalah kemampuan seseorang untuk berorentasi terhadap orang lain berupa perasaan simpati dan peduli terhadap orang lain yan ditimpa kemalangan atau masalah.

c. Personal Distress, adalah kemampuan seseorang untuk merasakan kecemasan yang mendalam ketika menhadapi situasi interpersonal yang tidak menyenangkan.

d. Fantasy, adalah kecenderungan seseorang untuk berimajinasi dalam perasaan dan tindakan pada karakter khayalan. 
Empat aspek tersebut merupakan item - item dari Davis (1980), yang dikenal dengan IRI (Interpersonal reactivity index).

Menurut Besel \& Yuille (2010) tiga komponen empati antara lain:

a. Kognitif empati yaitu memahami orang lain dengan mengetahui apa yang dipikirkan orang tersebut, dimensinya yaitu : prespektif taking

b. Emosional empati yaitu kemampuan untuk mengetahui emosi yang sedang dirasakan dan dialami orang lain, dimensinya yaitu : empati concent dan fantasy.

c. Social skill yaitu ketrampilan bersosial, kecepatan memberi respon, dimensinya dititik beratkan pada personal distress.

Aspek - aspek empati menurut Batson dan Ahmad (2008) ada empat yaitu:

a. Imagine-self perspective adalah aktivitas membayangkan bagaimana seseorang berfikir dan merasakan apabila ia berada pada kondisis dalam posisi orang lain, atau kecenderungan seseorang untuk mengambil sudut pandang orang lain secara spontan, individu ditekankan untuk mampu bersudut pandang pada perilaku non egosentrik, yaitu perilaku yang tidak diperioritaskan pada kepentingsn diri sendiri tapi kepentingan orang lain.

b. Imagine-other adalah kemampuan membayangkan bagaimana seseorang berfikir dan merasakan dalam situasi anggota keluarga -kelompok, membayangkan bagaimana outgroup anggota berpikir dan merasa.

c. Empathic concern atau perhatian empati adalah kemampuan seseorang untuk merasakan apa yang orang lain butuhkan. Orentasi seseorang terhadap orang lain butuhkan. Orentasi seseorang terhadap orang lain berupa perasaan simpati dan peduli terhadap orang lain yang ditimpa kemalangan.

d. Emotional matching adalah kemampuan seseorang untuk mengetahui perasaan orang lain, maka empathizer mampu memahami melalui penangkapan fenomena fisiologis yang dimunculkan oleh orang lain.

Adapun faktor - faktor yang mempengaruhi empati menurut Taufik (2012), ada beberapa hal antara lain: 
a. Gender. Hasil penelitian menunjukkan bahwa perempuan memiliki tingkat keakuratan empati lebih tinggi, tetapi hanya pada kondisi - kondisi tertentu. Pada kelompok pria sebaya didasarkan pada kegiatan bersama, seperti olahraga, karena anak laki - laki cenderung berintaraksi dalamkelompok yang lebih besar, kemungkinan laki - laki lebih terbiasa berinteraksi dengan rekan - rekan yang memiliki nilai - nilai dan keyakinan yang berbeda dari mereka sendiri.

b. Faktor kognitif. Keakuratan empati juga berkaitan dengan kecerdasan verbal (bahasa), orang yang memiliki kecerdasan verbal yang tinggi akan dapat berempati secara akurat dibanding dengan orang yang rendah kecerdasannya.

c. Faktor Sosial. Sosialisasi dilakukan seseorang karena mempengaruhi tingkat empati. Semakin banyak dan intensif sosialisasi seseorang semakin terarah kepekaannya terhadap emosi orang lain. Sosialisasi sangat berpengaruh terhadap empati, karena dalam sosialisasi, 1) Membuat seseorang mengalami banyak emosi, 2) membuat seseorang dapat mengamati secara langsung keadaan internal orang lain, 3) membuka kesempatan role taking, 4) terdapat banyak afeksi sehingga seseorang menjadi lebih terbuka terhadap kebutuhan emosi orang lain, 5) ditemukan banyak model yang dapat memberikan contoh mengenai kebiasaan pro-sosial dan perasaan empati yang dinyatakan secara verbal.

d. Status sosial ekonomi. Menurut Kraus dkk (2010, dalam Taufik, 2012) menyebutkan bahwa orang - orang yang berstatus rendah secara ekonomi, kehidupan mereka dipengaruhi oleh karakteristik konteks lainnya, seperti tingkat dukungan yang telah mereka terima. Oleh karena itu, orang - orang dengan status sosial rendah memungkinkan untuk mengubah perhatian mereka dari pengalaman - pengalaman dan pikiran - pikiran personal kepada kondisi lingkungan sekitar. Sehingga mereka lebih sensitive terhadap isyarat lembut dan gaya bicara orang lain, hal ini akan meningkatkan kapasitas mereka dalam memahami emosi target empati.

e. Hubungan dekat (Close Relationship). Hubungan antara akurasi empati dengan kualitas hubungan sangat kompleks.

\section{Hubungan Empati dengan Perilaku Altruistik}

Empati merupakan ketrampilan sosial yang mendasar yang memungkinkan individu untuk mengantisipasi, memahami ketrampilannya sehingga mendorong berperilaku artruistik. 
Freshbach mengangagap empati menjadi penentu penting transaksi sosial, empati juga tampaknya memainkan peran kunci dalam pengembangan pemahaman sosial dan perilaku sosial yang positif (Albiero dkk, 2009). Pada penelitian McMohan dkk (2005) menganggap empati sebagai preditor perilaku pro-sosial, kemampuan untuk memahami perpektif orang lain penting dalam pengembangan dan ekspresi perilaku pro-sosial.

Menurut Warneken \& Tomallo (2009), perilaku altruistik merupakan perilaku yang alamiyah, berhubungan dengan rasa sosial seseorang yang mampu menciptakan dan menumbuhkan jiwa yang altruistik. Kakavolis juga berpendapat bahwa ciri dari perilaku altruistik adalah adanya berbagi, membantu, bekerja sama dan memberikan hiburan (Leontopoulou, 2010).

Empati merupakan bagian intergral untuk memecahkan konflik dalam keluarga, sekolah, ruang rapat dan dalam peperangan, karena dalam empati terdapat kemampuan untuk berprespektif taking terhadap yang lain dan mengidentifikasi kesamaan melalui kesamaan yang sama dan perdamaian (Goedon, 2005 dalam Batson \& Ahmad, 2008). Menurut teori Waal bahwa dengan melihat emosi orang lain secara otomatis dengan tanpa sadar akan mengaktifkan sosialisasi pribadi seseorang, sehingga akan mampu untuk bereaksi terhadap pengalamanorang lain (preston \& de Waal 2002).

Menurut Eklund (2006) bahwa empati dan prespektif taking targetnya adalah melibatkan kepedulian terhadap orang lain (perilaku altruistik), karena dalam empati terhadap keprihatinan yang mendalam. Dalam penelitian Batson (2008) dinyatakan bahwa empati dapat mendorong seseorang untuk melakukan perilaku altruistik. Mengamati seseorang yang membutuhkan bantuan dapat membangkitkan rasa kepedulian/empatik untuk orang lain, kemudian termotivasi untuk membantu. Dalam hipotesis empati-altruisme disebutan bahwa kepedulian empatik dikaitkan dengan afektif seseorang yang menderita (bukan pada diri sendiri), dank arena itu mempromosikan motivasi yang benar - benar tanpa pamrih untuk memberikan bantuan atau berperilaku altruistic (Maner \& Gailliot, 2006).

Berdasarkan pembahasan penelitian diatas, dapat disimpulkan bahwa sebelum berperilaku altruistik, pada seseorang terdapat proses keprihatinan dan berprespektif taking yang merupakan aspek empati. Dengan empati seseorang akan lebih sosial, lebih pemaaf, mampu 
bekerja sama dan mampu berinteraksi dengan lainya. Perilaku altrustik mampu dilakukan seseorang apabila memiliki karakteritik - karakterik empati.

\section{Tujuan Penelitian}

Tujuan penelitian ini adalah untuk mengetahui hubungan antara empati dengan perilaku altruistik pada santri pondok pesantren Al-Asy'ari Ceweng Dander Bojonegoro

\section{METODE PENELITIAN}

Penelitian ini menggunakan metode kuantitatif. Data diambil dengan menggunakan skala empati dan skala perilaku Altrustik. Skala empati disusun berdasrkan Ambrosio (2009), yang diperjelas teori Davis (1980) pada Interpersonal Reactivity Index (IRI) yang meliputi : (1) Perspective Taking, (2) Personal Distress, (3) Empathic Concern, (4) Fantasy. Adapun skala perilaku altruistic disusun berdasarkan teori Einserberg dan Mussen (Dayakisnin \& Hudaniah, 2003) skala terdiri dari beberapa komponen, meliputi: 1) Generosity, 2) Cooperative, 3) Honesty dan 4) Helping.

Subjek penelitian ini adalah santri pondok pesantren Al-asy'ari Bojonegoro yang seluruhnya berjenis laki- laki dengan jumah 167 santri. Adapun tehnik pengambilan sampel adalah dengan menggunakan Proportional Stratified random sampling yaitu suatu teknik yang digunakan bila polulasi mempunyai anggota yang tidak homogen dan berstata secara proposional (Sugiyono, 2013). Subjek dimbil dari santri yang berusia remaja dengan jumlah 90 santri yaitu pada santri di tingkat kedua (usia 12-15 thn) dengan jumlah 30 santri, tingkat ketiga (usia 16-19 thn) dengn jumlah 33 santri, dan tingkat ke empat (usia 20-25 tahun) dengan jumlah 27 santri.

Metode analisis yang digunakan dalam penelitian ini berupa analisis regresi. Analisis ini digunakan untuk menggabbarkan pola hubungan antara variable dependent (variable terikat) dengan variabel independent (varibel bebas), yaitu hubungan antara empati dengan perilaku altruistic. Analisis data penelitian ini menggunakan bantuan progam statistik SPSS for Windows 16.0.

\section{Hasil Analisis Data}

\section{Uji Asumsi}




\section{a. Uji Normalitas Sebaran}

Uji normalitas sebaran dilakukan untuk mengetahui apakah data memiliki distribusi normal atau tidak sebagai syarat representative sampel penelitian. Uji normalitas sebaran dari variable perilaku altruistic diperoleh nilai Kolmogorov-Smirnov $Z=0,682$, signifikans $(p)=0,741(p>0,05)$ yang berarti sebarannya normal. Uji normalitas sebaran dari variable empati diperoleh nilai Kolmogorov-Smirnov $Z=0,888$; signifikans $(\mathrm{p})=$ $0,409$ ( $p>0,05)$ yang berarti sebaranya normal.

\section{b. Uji Linieritas Hubungan}

Uji linieritas hubungan bertujuan untuk mengetahui apakah variable bebas (empati) dengan variable tergantung (perilaku Altruistik) memiliki korelasi yang searah (linier) atau tidak. Variabel empati dengan perilaku altruistik mempunyai korelasi Linier, hal ini ditunjukkan oleh nilai Flinearity $=63,775$ signifikansi $(p)=0,467(p>0,05)$

\section{Uji Hipotensi}

\section{a. Analisis regresi sederhana}

Setelah dilakukan uji asumsi, maka dilakukan perhitungan untuk menguji hipotesis penelitian yaitu dengn menggunakan metode analisis regresi sederhana, yang digunakan untuk mengetahui pengaruh variabel bebas terhadap variabel tergantung (perilaku altruistik). Berdasarkan hasil analisis diperoleh, diperoleh bahwa nilai $\mathrm{R}$ sebesar 0,664 dan nilai Fregresi $=63,705$ signifikansi $(\mathrm{p})=0,000(\mathrm{p}<0,01)$. Hal ini menunjukkan ada hubungan positif antara empati dengan perilaku altruistik, berarti hipotesis yang mnyatakan "ada hubungan antara empati dengan perilaku altruistic" diterima.

\section{b. Analisis Korelasi}

Hasil analisis data hubungan antara empati dengan perilaku altruistic dapat dilihat pada tabel berikut : 


\begin{tabular}{|l|l|l|l|l|l|l|l|l|l|}
\hline Model & & $\begin{array}{l}\text { Unstandardized } \\
\text { Coefficients }\end{array}$ & $\begin{array}{l}\text { Standardized } \\
\text { Coefficients }\end{array}$ & T & Sig. & \multicolumn{3}{|c|}{ Corelation } \\
\hline & & B & $\begin{array}{l}\text { Std. } \\
\text { Error }\end{array}$ & Beta & $\begin{array}{l}\text { Zero- } \\
\text { order }\end{array}$ & Partial & Part & B & $\begin{array}{l}\text { Std. } \\
\text { Error }\end{array}$ \\
\hline & Contant & 33,101 & 7,458 & & 4,438 & 0,000 & & & \\
\hline & Empati & 0,743 & 0,093 & 0,664 & 7,982 & 0,000 &, 664 &, 664 &, 664 \\
\hline
\end{tabular}

Berdasarkan tabel diatas, analisis korelasi antara vareabel empati dengan variabel perilaku altruitik diperoleh rxy sebesar 0,664 dengan $p=0,000(p<0,01)$ berarti ada hubungan positif yang sangat signifikan antara empati dengan perilaku altruistic, semakin tinggi empati santri maka semakin tinggi perilaku altruistic santri. Hasil ini juga menunjukkan bahwa hipotesis yang berbunyi “ ada hubungan antara empati dengan perilaku altruistik" diterima.

\section{c. Analisis Koefisien Determinasi}

Analisis ini dilakukan untuk mengetahui besarnya sumbangan variabel bebas terhadap variabel tergantung.

\begin{tabular}{|r|r|r|r|r|}
\hline Model & \multicolumn{1}{|l|}{ R } & \multicolumn{1}{|l|}{ R Square } & Adjusted R Square & Std. Error of estimate \\
\hline 1 & $.664^{\mathrm{a}}$ & .440 & .433 & 4.120 \\
\hline
\end{tabular}

a. Dependent Variable : Altruistic

Berdasarkan hasil tabel diatas, diketahui bahwa empati memiliki kontribusi $44 \%$ terhadap perilaku altruistik, sedangkan sisanya dapat dipengaruhi atau dijelaskan oleh variabel - variabel lainya, seperti faktor mood, tekanan waktu, sifat dari penolong, religiusitas dan lain - lainya.

\section{Katagorisasi}

\section{a. Empati}

Variabel empati mempunyai nilai rerata empirik sebesar 79, 96 dan rerata Hipotetik sebesar 57, 5 yang berarti empati pada subjek penelitian tegolong sangat Tinggi.

\section{b. Perilaku Altruistik}


Variabel perilaku altruistic mempunyai nilai rerata empirik sebesar 92,52 dan rerata hipotik sebesar 60 yang berarti perilaku altruistic pada subjek penelitian tergolong sangat tinggi.

\section{Pembahasan Hasil Penelitian}

Hasil penelitian menyatakan bahwa: 1) ada hubungan positif yang sangat signifikan antara empati dengan perilaku altruitik, 2) semakin tinggi nilai empati santri maka semakin tinggi pula nilai perilku altruistik santri, begitu juga sebaliknya. Berdasarkan hasil analisis tersebut maka hepotesis dapat diterima.

Hasil analisis regresi sederhana diperoleh $\mathrm{R}$ sebesar 0,664 dan nilai Fregresi $=63,705$ signifikansi $(\mathrm{p})=0,000(\mathrm{p}<0,01)$. Berarti memperlihatkan adanya pengaruh yang signifikan antara empati terhadap perilaku altruistik, dimana daya ramal diketahui 0,440, maka pengaruh empati terhadap perilaku altruistik sebesar $44 \%$.

Hasil analisis data empati dana perilaku altruistik menunjukkan koefisien korelasi $\left(\mathrm{r} \mathrm{x}^{2} \mathrm{y}\right)$ sebesar 0,664 dengan $\mathrm{p}=0,000(\mathrm{p}<0,01)$ berarti ada hubungan yang signifikan antara empati dengan perilaku altruistik pada santri. Semakin tinggi empati santri maka semakin tinggi nilai perilaku altruistic dan sebaliknya semakin rendah empati santri maka semakinrendah pula perilaku altruistic santri. Temuan ini didukung oleh Batson (2008) menyatakan bahwa dengan empati dapat mendorong seseorang untuk melakukan perilaku altruistik. Mengamati seseorang yang membutuhkan bantuan dapat membangkitkan rasa kepedulian/empatik untuk orang lain, kemudian termotivasi untuk membantu.

Empati merupakan bagian intergral untuk memecahkan konflik dalam keluarga, sekolah, ruang rapat dan dalam peperangan, karena dalam empati terdapat kemampuan untuk berprespektif taking terhadap yang lain dan mengidentifikasi kesamaan melalui kesamaan yang sama dan perdamaian (Goedon, 2005 dalam Batson \& Ahmad, 2008). Menurut teori Waal bahwa dengan melihat emosi orang lain secara otomatis dengan tanpa sadar akan mengaktifkan sosialisasi pribadi seseorang, sehingga akan mampu untuk bereaksi terhadap pengalamanorang lain (preston \& de Waal 2002). 
Menurut Eklund (2006) bahwa empati dan prespektif taking targetnya adalah melibatkan kepedulian terhadap orang lain (perilaku altruistik), karena dalam empati terhadap keprihatinan yang mendalam. Dalam penelitian Batson (2008) dinyatakan bahwa empati dapat mendorong seseorang untuk melakukan perilaku altruisti. Mengamati seseorang yang membutuhkan bantuan dapat membangkitkan rasa kepedulian/empatik untuk orang lain, kemudian termotivasi untuk membantu

Menurut kakavolis (Leontopoulou, 2010), ciri dari perilaku altruistik adalah adanya berbagi, membantu, bekerja sama dan memberikan hiburan. Banyak temuan penelitian menunjukkan bahwa suasana hati yang baik dan kebahagian dapat memfasilitasi altruisme. Hipotesis ini karena adanya simpati atau empati bagi yang membutuhkan yang merupakan motif untuk kegiatan altruistic (Habito \& inaba, 2006). Menurut Maner \& Galilliot (2006), menunjukkan bahwa empati sebaagai motivator perilaku altruistikdan mengendalikan egoistic motivator, kepedulian empatik dikaitkan dengan kesediaan peserta untuk membantu saudara walaupun orang asing.

\section{KESIMPULAN}

Berdasarkan hasil penelitian ini, dapat diambil kesimpulan :

1. Ada hubungan yang signifikan antara empati dengan perilaku altuistik santri, apabila nilai empati santri naik maka nilai perilaku altruistik santri juga naik.

2. Sumbangan efektif atau peranan empati terhadap perilaku altruistik diketahui 0,440 , atau $44 \%$, berarti $66,4 \%$ dipengaruhi oleh variabel luar

\section{Saran - Saran}

Dengan adanya penelitian ini diharapkan memberikan kontribusi bagi :

\section{Santri}

Penanaman pendidikan karakter seperti : bersosialisasi, tolong menolong, gotong royong dalam kebaikan, kerjasama dan berukhuwah islamiyyah pada santri harus tetap ditananmkan, dibiasakan dan dilatih. Menumbuhkan rasa simpati dan empati pada santri merupakan proses yang harus terus digali, apalagi di pesantren kegiatan apapun selalu 
mengedepankan akan kebersamaan, akan mengalami kesulitan bagi santri yang tidak memiliki rasa empati yang tinggi. Bagi santri yang memiliki nilai empati yang tinggi tinggal di pondok pesantren terasa nyaman dan menyenagkan.

\section{Orang tua / para Pembimbing (asatidz)}

Bagi orang tua dan para asatidz agar selalu memberi suri tauladan dan bimbingan pada santri untuk selalu bersikap peduli terdapat diri sendiri, orang lain dan lingkunganya, serta mengedepankan jiwa menolong karena hal tersebut merupakan aspek perkembangan yang harus terus ditingkatkan.

\section{Institusi/Lembaga Pendidikan}

Pada Institusi/lembaga pendidikan khususnyapondok pesanren hendaknya selalu menciptakan suasana yang penuh dengan empati, sehingga perilaku altruistik merupakan perilaku yang sudah membudaya bagi santri, suasana nyaman dengan nuansa seallu bergotong royong, tolong menolong, kebersamaan dapat tercipta selalu.

\section{Daftar Pustaka}

Afiatin, T., (2012). Pendidikan Karakter Remaja dalam Keluarga, Psikologi untuk Kesejahteraan Masyarakat, (Universitas Gadjah Mada pustaka Pelajar, Yogyakarta)

Albiero, P., Martricardi, G., Speltri, D., \&Toso, D. (2009). The Assessment of Empathy in Adolescence: A contributin to the Italian validation of the "basic Empathy Scale". Journal of Adolescence, 32:393-408.

Ali, Z,A., \& Shah, S.S.,(2012), Altruism and Belief just Word in Young Adults: relationship with Religionsity, journal of Clinical psychology, Pakistan, 2.35 - 46

Baron, A.R.,Branscombe, R.N.,\&Byrne, D.E., (2003), Psikologi Sosial. (alih bahasa : Ratna Djuwita dkk). Jakarta: Erlangga.

Batson, C.D., \& Ahmad, Y.N., (2009) Using Empathy to Improve Intergroup Attitudes Psychology, University of Kansas, 1-30. 
Batson, C.D., (2008). Empathy- Induced Altruistic Motivation, Journal of Department of Psychology, University of Kansas, 1-30.

Besel, D.L., Yuille, J.C., (2010). Individual Differences inEmpathy: the role of Facial Expression Recognition, Journal of Personality and Individual Differences, 49: 107-112.

D’Ambrosio, F., Besche, C., Didon., \& Olivier, M., (2009). The Basic Empathy Scale: A French Validation of a Measure of Empathy in Youth. Journal of Personality and Individual Defferences. 45:160-165

Davis, H.M., A Multimensional Approach to Individual Differences is Empathy, the university of Texas at Austin JSAS Catalog of Selected Documents in Psychology, 1980, 10, p.85

Dovidio, J.E., Panner, A.l., Piliavin, A,.J., \& Scroeder, A.D., (2006), Prosocial Behavior: Multivel Prespectives, annu.Rev. Psychol.56:14.1-14.28

Elizabeth, S., (2011). Stress \& altruisme. Diakses dari http/www.stress.about.com/od/.../altruisme.htm

Enklund, S., (2006). Empathy and Viewing the other of Subject, Scandinavian Juurnal of Psychology, 47, 399-409.

Finn, E.S., (2008). The Many Faces of Empathy in Experiential, person-Centered, Collaborative Assessment. Journal of personality Assessment. Texas, 91:20-23

Gailliot, T.M., \& Maner, K.J., (2007). Altruism and Egoism : Prosocial Motivations for Helping depend on Relationship Context, European journal of Social Psychology, 37: 347-358.

Habito, R.L.F., \& Inaba, K., (2008). The practice of Altruis Caring and Religion in Global Prespective. New York: Cambridge Scholar Publishing.

Kurniawan, S., (2012). Pentingnya Pendidikan Karakter, Catatan Harian Syamsul, diakses dari $\mathrm{Http} / \mathrm{www} /$ catatansyamsul.com

Laventhal, H. D., (2009). Altruism and Volunteeris: the perception of Altruism in four Diciplines and their Impacton the Study of Volunteerism, journal for the theory of social Behavior. 39:3, 0021-8308. 
Leontopoulou, S., (2010). An exploratory Study of Altruism in Greek Children: Relations with Empathy, Resilience and classroom climate, Scientific Research. Vol 1.377-385

McMahon, D.S.,Wernsman, J., \& Parnes, L.A., (2005), Adolescent Health Brief: Understanding prosocial Behavior: The Impact of Empathy and Gender among African, American Adolescent, Journal of Adolescent Health, DePaul University, Chicago, Vol 39.135-137.

Myears, G. David., (2012). Psikologi Sosial, Salemba Humanika, Jakarta

Preston, D. S, \& Frans, D. W., (2002). Empathy: Its Ultimate and Proximate Base, Behavioral and Brain Scinces 25, 1-72, Printed in the States of America, Cambidge University Press.

Sarwono, W. S., \& Meinarno, A.E., (2011), Psikologi Sosial, (Salemba Humanika, Jakarta)

Sugiono, (2013), Statistik untuk Penelitian, (Alfabeta, Bandung)

Taufik., (2012) Empati Pendekatan Psikologi Sosial, (Raja Grasindo Persada, Jakarta).

Tomallo, M. \& Warneken, F. (2009), The Roots of Altruism, British Journal of Psychology, $100,(455-471)$. 